\title{
Relationship between Empowerment and Job Satisfaction among Staff Nurses in Minia University Hospital
}

\author{
Doaa Hamdy Abdelhamied ${ }^{1}$; Mona Mustafa Shazly $^{2}$; Sahar Ahmed Abood ${ }^{1}$ \\ Corresponding author: Doaa Hamdy Abdelhamied \\ Email: doaahamdy70@yahoo.com \\ 1 Nursing Administration department, Faculty of Nursing, Minia University. \\ 2 Nursing administration department, Faculty of Nursing, Ain Shams University.
}

\begin{abstract}
Background: The nursing staff plays an important role for organizational achievement. Therefore, it is very important for the nurse managers to recognize nurses' work and provide them with opportunities to grow and to look after their comfort. Aim of the study: to assess the relationship between empowerment and job satisfaction among staff nurses in Minia university Hospital through, identifying the level of structural and psychological empowerment, determining the level of job satisfaction and finding out the relationship between empowerment and job satisfaction. Research design: A descriptive cross sectional research design. Sample: consisted of all available staff nurses (300 nurse) working in the units during the period of data collection. Setting: conducted in Minia University Hospital. All units were included in the study. Tools of data collection: includes three tools, tool I: included two parts: part 1: A demographic sheet, part 2: the Conditions for work Effectiveness Questionnaire-II (CWEQ-II), tool II: psychological empowerment scale, and tool III: job satisfaction scale were used. Results: Near to two third of studied nurses $(62.7 \%)$ have low structural empowerment level compared to near to half of studied nurses $(49.7 \%)$ had low psychological empowerment level. More than two third of staff nurses have low job satisfaction (68.3\%). Conclusion: the impact of empowerment on nurses' work environments and understanding the relation between empowerment and job satisfaction might be useful for creating a supportive and satisfying work environment for nurses, which in turn could promote the intention to stay. Recommendation: Nurse Mangers should assess the structures in their organizations to identify barriers of staff nurses to feel job security, ensure empowering factors at work, providing access to organizational empowering structures in order to make their employees have a greater sense of autonomy and impact at the workplaces

Keywords: Empowerment, Job Satisfaction, Staff Nurses.
\end{abstract}

\section{Introduction}

Nursing is a dynamic profession in which nurses are increasingly given greater responsibility and providing more complex nursing care. Nurses face many challenges in the health care system due to ongoing healthcare restructuring and policy reform (1). The challenges include fewer available resources, more complex patients, reduced opportunities for education and training, and increased job insecurity and job stress $^{(2)}$. These difficulties yield negative effects on the health care system such as decreased nurse retention, increased nursing shortage, and increased recruitment costs for healthcare institutions ${ }^{(3-4-5)}$. Enhancing nurses' job satisfaction could be a solution for these adverse effects, especially for the nursing shortage ${ }^{(3)}$.

Empowerment can be defined as the process of sharing power with employees, thereby enhancing their confidence in their ability to perform their jobs and their belief that they are influential contributors to the organization ${ }^{(6)}$ Empowerment is also considered to be the interrelationship between authority, resources timely and accurate information and accountability ${ }^{(7)}$.

There are two complementary perspectives on empowerment at work . The First one is a macro focus on the structural conditions that enable empowerment. The second is a macro focus on the psychological experience of empowerment at work. Structural empowerment focuses on empowering structures, policies and practices. Psychological empowerment focuses on employees' perceptions and reactions to structures, policies and practices in which they are embedded ${ }^{(8)}$.

Empowerment is one of the most effective tools for increasing employee productivity and efficient use from capacities and abilities of the individual and group according to
Organizational goals ${ }^{(9)}$.The process of empowerment increases creativity and initiative of people and individuals committed to work more and increases job satisfaction ${ }^{(10)}$ Empowerment improve organization effectiveness and increase the flexibility and dynamism organization and knowledge and skills ${ }^{(11)}$.

Job satisfaction is one of the most important factors in organizations as it is related to organizational effectiveness ${ }^{(12) .}$ Job satisfaction in nursing is associated with nurse performance, quality of patient care and increased patient satisfaction ${ }^{(13)}$. Therefore, enhancing the job satisfaction of nurses is important in health care. Job satisfaction is a multifaceted concept associated with many factors such as working conditions, organizational support, leadership styles, leader empowering behaviors, structural empowerment and psychological empowerment $^{(5)}$.

Nursing leaders must create work environments that support the bedside nurse in participatory decision-making. Creation of such work environment solidifies the relationship between empowered work environments and patient outcomes. Nursing leaders should create and sustain an environment that is trusting, improves job satisfaction, and provides a shared governance model for decision making. Nurses want work activities that are challenging, learning opportunities, acquisition of technical knowledge and skills, growth opportunities and autonomy to practice ${ }^{(14) .}$

\section{Significance of the study}

Through work in Minia University Hospital, it was found that staff nurses are complaining of powerlessness, lack of independence and job dissatisfaction. There are few studies about the empowerment and job satisfaction at Minia University. In Egypt, studies show that $41 \%$ of staff nurses had structural empowerment, while $53 \%$ had job satisfaction ${ }^{(15)}$. 
Therefore it was felt necessary to study the relationship between empowerment and job satisfaction among staff nurses.

\section{Aim of the study}

The aim of the current study is to assess the relationship between empowerment and job satisfaction among staff nurses in Minia university hospital through:

1)Identifying the level of structural and psychological empowerment among staff nurses in Minia university hospital.

2)Determining the level of job satisfaction among staff nurses in Minia university hospital.

3)Finding out the relationship between empowerment and job satisfaction among staff nurses in Minia university hospital.

\section{Research questions:}

- What is the level of empowerment among staff nurses?

- What is the level of overall nurses' job satisfaction?

- Is there a relation between empowerment and job satisfaction among staff nurses?

\section{Subjects and Methods \\ Research design:}

A descriptive correlational research design was used in conducting this study to fulfill the study aim.

\section{Setting:}

The study was conducted at Minia university hospital .All units were included in the study in Minia governorate.

\section{Subjects:}

The subjects of the study sample consisted of all available staff nurses working in the all units during the period of data collection. Their total number is 300 nurses. The inclusion criteria for this study sample include: full time staff nurses who have a minimum of 1 year' nursing experience (new nurses may need time to be familiar with the hospital structure and its policy).

\section{Tools of Data collection:}

Three tools were used in this study for data collection

Tool I: A self - administration questionnaire sheet

It was used for collecting the data for this study. It consists of two main parts:

Part one: this part concerned with data pertaining socio-demographic characteristics of the study subjects as: age, sex, nursing qualification, educational level, current position, area of work, and years of experience.

Part two: this part consisted of The Condition of Work Effectiveness Questionnaire-II (CWEQ-II). This part aimed to identifying the level of structural empowerment among staff nurses. This tool developed by Laschinger and colleagues (2001) ${ }^{(16)}$ a modification of the original CWEQ. It consists of 19 items. These items were grouped under 6 components of structural empowerment described by Kanter $(1993)^{(17)}$.

Tool II: Psychological Empowerment Scale (PES)

It was used to identifying the level of psychological empowerment among staff nurses. This tool developed by Spreitzer's (1995)(18). It consists of 12 items. These items were grouped under four theoretical dimensions.

Scoring system: responses were scored under five point likert scale ranging from one to five in which $1=$ Strongly Disagree, $2=$ Disagree, $3=$ To some extent, 4= Agree, and $5=$ strongly Agree. All dimensions (four dimensions) had a positive scoring. The overall scores of each dimension are calculated by taking the average (total scores divided by the number of items) of the respondent's score for each dimension and multiplying this by 100 to convert it into percent score.

If the total scores were less than $50 \%$ considered as low psychological empowerment. If the total scores ranged from $50 \%-75 \%$ considered as moderate psychological empowerment, and if the total scores were $75 \%$ or more considered as high psychological empowerment .

Scoring system of total empowerment: by sum two scales (structural empowerment plus psychological empowerment). If the total scores were less than $50 \%$ considered as low empowerment. If the total scores ranged from $50 \%-75 \%$ considered as moderate empowerment, and if the total scores were $75 \%$ or more considered as high empowerment.

Tool III: Job Satisfaction scale:

It was used to determining the level of job satisfaction among staff nurses. This tool developed by McCloskey and Mueller (1990)(19). It consists of 25-items. These items were grouped into five components.

Scoring system: responses were scored under five point Likert scale ranging from one to five in which $1=$ very dissatisfied, $2=$ dissatisfied, $3=$ to some extent, $4=$ satisfied, and $5=$ very satisfied. All components (five components) had a positive scoring. The overall scores of each component are calculated by taking the average (total scores divided by the number of items) of the respondent's score for each component and multiplying this by 100 to convert it into percent score.

If the total scores were less than $50 \%$ considered as low job satisfaction. If the total scores ranged from $50 \%-$ $75 \%$ considered as moderate job satisfaction, and if the total scores were $75 \%$ or more considered as high job satisfaction.

\section{Tools Validity and reliability}

The tools were submitted to a panel of five experts in in the field of nursing administration at Minia and Ain shams university confirmed its validity. Modifications on the tools were done according to the panel judgment in relation to appropriateness of the content and sequence accuracy of items.

Reliability of the tools (tool I, II, III) were performed to confirm validity of tool and calculated statistically. The internal consistency measured to identify the extent to which the items of the tool measure the same concept and correlate with each other by Cronbach's alpha test were $.92, .92$ and .95 respectively

\section{Pilot study:}

A pilot study was carried out after the development of the tools and before starting the actual data collection, on 30 staff nurses. The aim of the pilot study was to test the feasibility of the study, the sequence of items, and finally clarity and applicability of the preliminary tool. It also served to estimate the time required for filling the questionnaire sheets which was 20 minutes. They were included in the main study subjects during the actual collection of data. The process of pilot study took two weeks'(from15/6 to 30/6) in June 2016.

\section{Ethical consideration:}

A written initial approval was obtained from the 
research ethical committee of the faculty of nursing, Minia University. The researcher introducing herself to the directors and discussed the aim of the study, then met the head nurse of each department, and introducing herself with discussed the aim of the study and determined the suitable time to meet the study participants and collect the data. Nurses were reassured that all information obtained was confidential and would not affect their professional evaluation.

\section{Data collection procedure:}

The official approvals were obtained from medical and nursing administration of Minia university hospital. Prior to collection of data, a formal letter issued from the dean of post graduate studies and research at faculty of Nursing, Minia university, and the approval of ethical committee. Submitted to medical and nursing administrations and the heads of the units for obtaining their permission and help to conduct the study. The letters also listed the data needed for the study. Moreover, a written consent was obtained from each participant. Before the nurses participate in this study, the nature, the aim, methods, and anticipated benefits of the study was explained. The researcher informed the participation is voluntary and they have rights to withdrawal at any time without giving any reasons.
Before distribution the questionnaire, the research met the participants according to the time which determined by head of each department, introducing herself and explained the purpose of the study and the components of the tools to the participants in the study setting. Then, the researcher distributed the data collection sheets to respondents individually in their workplace. The filling time for the questionnaire sheet took about 20 minutes. The researchers checked the completeness of each filled form after the participant filled it. Data collection was done during the morning, afternoon, and night shifts two days / week, June, to November 2016.

\section{Statistical design:}

Statistical analysis was done by using Statistical Package for the Social Science (SPSS 20.0). Quality control was done at the stages of coding and data entry. Data were presented by using descriptive statistics in the form of frequencies and percentage for qualitative variables, and mean \& standard deviation (SD) for quantitative variable. Correlation coefficient test was also used between empowerment and job satisfaction and statistical significance was considered at $\mathrm{p}<0.05$.

\section{Results}

Table 1: Personal Characteristics of staff nurses in the study sample $(\mathrm{n}=300)$.

\begin{tabular}{|c|c|c|}
\hline Personal data & No. & $\%$ \\
\hline \multicolumn{3}{|l|}{ Gender } \\
\hline Male & 123 & 41.0 \\
\hline Female & 177 & 59.0 \\
\hline \multicolumn{3}{|l|}{ Age / years } \\
\hline $18-32$ & 174 & 58.0 \\
\hline $32-45$ & 97 & 32.3 \\
\hline $45-58$ & 19 & 9.7 \\
\hline Mean $\pm \mathrm{SD}$ & \multicolumn{2}{|c|}{$32.6 \pm 9.6$ years } \\
\hline \multicolumn{3}{|c|}{ Years of experience in current work } \\
\hline $1-$ & 159 & 53.0 \\
\hline $11-$ & 67 & 22.3 \\
\hline 21 & 61 & 20.3 \\
\hline $31-40$ & 13 & 4.4 \\
\hline Mean $\pm \mathrm{SD}$ & \multicolumn{2}{|c|}{$12.9 \pm 9.9$ years } \\
\hline \multicolumn{3}{|c|}{ Years of experience in current department } \\
\hline $1-$ & 153 & 51.0 \\
\hline $11-$ & 70 & 23.3 \\
\hline 21 & 62 & 20.7 \\
\hline $31-40$ & 15 & 5.0 \\
\hline Mean \pm SD & \multicolumn{2}{|c|}{$13.2 \pm 9.9$ years } \\
\hline \multicolumn{3}{|l|}{ High Educational level } \\
\hline Diplom in Nursing & 157 & 52.3 \\
\hline Institute in Nursing & 123 & 41.0 \\
\hline B. Sc in Nursing & 19 & 6.3 \\
\hline Master degree & 1 & 0.4 \\
\hline \multicolumn{3}{|l|}{ Hours of Work /day } \\
\hline 6 & 213 & 71.0 \\
\hline 12 & 87 & 29.0 \\
\hline Mean \pm SD & \multicolumn{2}{|c|}{$7.7 \pm 2.7$} \\
\hline Total & 300 & 100 \\
\hline
\end{tabular}

Table 1 shows that, the largest proportion of staff nurses were in the age group $18-<32$ years $(58 \%)$. The mean of subject's age was 32.6 \pm 9.6 years. Concerning years of experience in current work and current department, more than half of staff nurses (53.0\% \% 51.0\% respectively) had experience less than 11 years. 
Minia Scientific Nursing Journal (Print) (ISSN 2537-012X) Vol. (1) No. (1) June 2017

Table 2: Mean score for the sources of structural empowerment in the study sample $(\mathrm{n}=300)$

\begin{tabular}{cll}
\hline Structural Empowerment sources & Min - Max & Mean \pm SD \\
\hline Opportunity & $3-15$ & $9.0 \pm 2.8$ \\
Information & $3-15$ & $6.1 \pm 3.1$ \\
Support & $3-15$ & $7.5 \pm 3.5$ \\
Resources & $3-15$ & $7.0 \pm 2.6$ \\
Informal power & $4-20$ & $11.5 \pm 3.1$ \\
Formal power & $3-15$ & $4.5 \pm 2.3$ \\
Structural empowerment & $24-94$ & $45.6 \pm 13.9$ \\
\hline
\end{tabular}

Table 2 summarized that informal power was the highest empowerment source with mean score $11.5 \pm 3.1$ while formal power was rated as the last empowering source with mean score $4.5 \pm 2.3$.

Table 3: Mean scores for the sources of psychological empowerment in the study sample $(n=300)$

\begin{tabular}{cll}
\hline Psychological Empowerment sources & Min - Max & Mean \pm SD \\
\hline Meaning & $3-15$ & $9.7 \pm 2.4$ \\
Competence & $3-15$ & $10.7 \pm 2.3$ \\
Autonomy & $3-15$ & $7.6 \pm 3.3$ \\
Impact & $3-15$ & $5.4 \pm 3.2$ \\
Psychological Empowerment & $15-60$ & $33.4 \pm 9.2$ \\
\hline
\end{tabular}

Table 3 mentioned that, competence power was the highest psychological empowerment source with mean score $10.7 \pm$ 2.3 while impact power was rated as the last psychological empowering source with mean score 5.4 \pm 3.2 .

Table 4: Mean scores for the level of job satisfaction in the study sample $(\mathrm{n}=300)$

\begin{tabular}{lll}
\hline Items & Min - Max & Mean \pm SD \\
\hline Work culture and conditions & $7-35$ & $14.2 \pm 6.2$ \\
Scheduling and family/ work balance & $8-37$ & $22.0 \pm 6.2$ \\
Collegial relationship & $5-25$ & $11.9 \pm 4.6$ \\
Extrinsic rewards & $3-15$ & $6.2 \pm 2.9$ \\
Professional opportunities & $2-7$ & $2.6 \pm 1.2$ \\
Job Satisfaction scale & $27-107$ & $56.8 \pm 17.4$ \\
\hline
\end{tabular}

Table 4 noticed that, Scheduling and family/ work balance was the highest job satisfaction source with mean score $22.0 \pm 6.2$ while Professional opportunities was rated as the last job satisfaction source with mean score $2.6 \pm 1.2$.

Table 5: Relation between empowerment and job satisfaction among study group in the study sample $(\mathrm{n}=300)$.

\begin{tabular}{lcccccccc}
\hline \multirow{2}{*}{ Satisfaction } & $\begin{array}{c}\text { Low empowerment } \\
(\mathrm{n}=174)\end{array}$ & $\begin{array}{c}\text { Moderate } \\
\text { empowerment } \\
(\mathrm{n}=104)\end{array}$ & $\begin{array}{c}\text { High empowerment } \\
(\mathrm{n}=22)\end{array}$ & $\mathrm{X}^{2}$ & $\mathrm{P}-$ value \\
\cline { 2 - 7 } & $\mathrm{No}$ & $\%$ & No & $\%$ & No & $\%$ & \\
Low job satisfaction & 168 & 96.6 & 35 & 33.7 & 2 & 9.1 & \\
Moderate job satisfaction & 6 & 3.4 & 66 & 63.5 & 17 & 77.3 & \multirow{2}{*}{165.822} & $.000 *$ \\
High job satisfaction & 0 & .0 & 3 & 2.9 & 3 & 13.6 & \\
\hline
\end{tabular}

*highly statistical significance

Table 5 showed that, $96.6 \%$ of studied group have low empowerment have low job satisfaction, $63.5 \%$ who have moderate empowerment have moderate job satisfaction whereas $13.6 \%$ who have high empowerment have high job satisfaction with a highly statistical significance difference between level of empowerment and job satisfaction in which $p-$ value $\leq .000$.

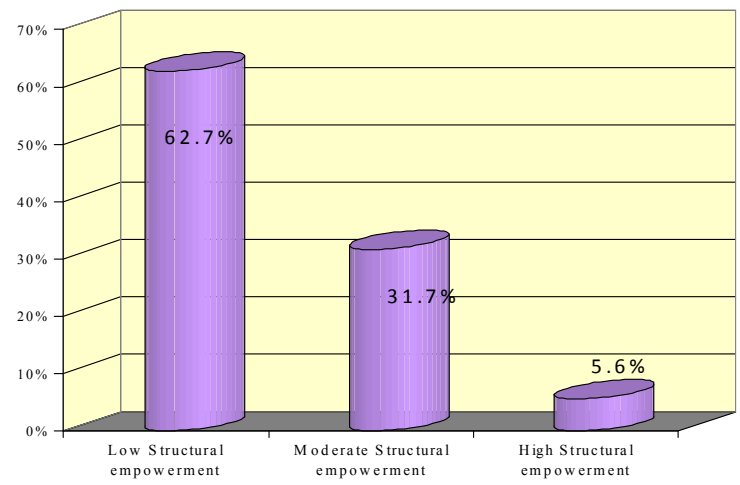

Fig. (1): level of structural empowerment among studied nurses

Figure 1 showed the level of structural empowerment among studied nurses. Near to two third of studied nurses $(62.7 \%)$ have low structural empowerment level. While near to one third of them have moderate structural empowerment (31.7\%), and only $5.6 \%$ of them have high structural empowerment level. 


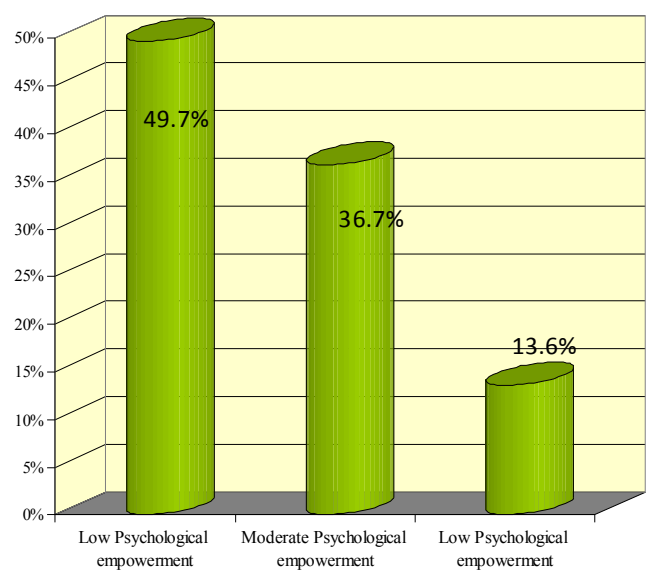

Fig. (2): level of Psychological empowerment among studied nurses

Figure 2 illustrated level of Psychological empowerment among studied nurses. Near to half of studied nurses (49.7\%) had low psychological empowerment level. While more than two third of them have moderate psychological empowerment (36.7\%), and only $13.6 \%$ of them had high psychological empowerment level.

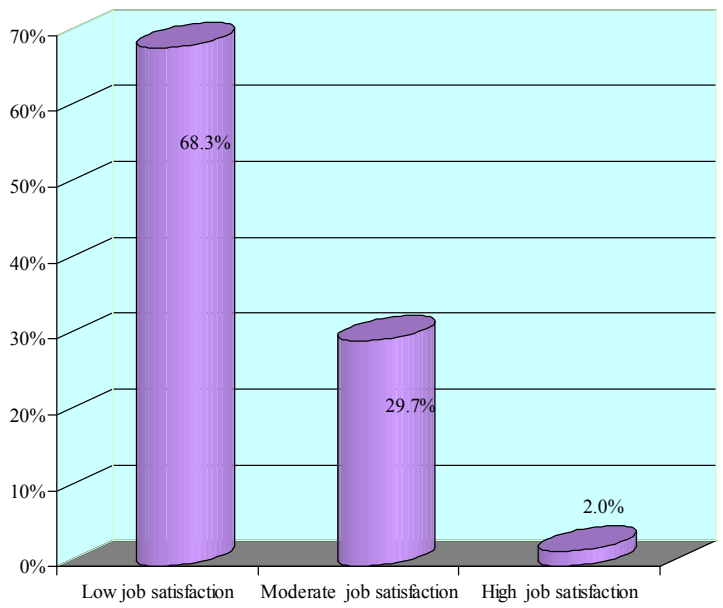

Fig. (3): level of job satisfaction among studied nurses

Figure (3) illustrated the level of job satisfaction among studied nurses. It noticed that more than two third of staff nurses have low job satisfaction (68.3\%). While, more than one quarter $(29.7 \%)$ have moderate job satisfaction and only $2 \%$ have high job satisfaction.

\section{Discussion}

The findings of the current study revealed that more than half of the study sample aged less than 32 years . this result might be attributed to that a lot of nurses in the last years in Minia university hospital changed their career by completing another study to be appointed in other departments inside their hospital. Other nurses choose traveling abroad because of unsuitable working conditions and inadequate salaries.

These results are consistent with (McNutt) ${ }^{(20)}$ who mentioned that if a nurse is not happy in a certain hospital or community because of compensation and management, she will look for a place that will provide her with the benefits she deserves. Personal issues can also cause a nurse to quit. This can include the issues she faces with her family. Nurses work on shifts like most service -oriented industries. Their schedule is a challenge to manage.

In the present study, more than half of the study subjects who work in Minia university hospital were females .This results might be attributed to the fact that the majority of nurses who graduated from secondary diploma school and clinical institute were females .This is supported by (Yousef) (21) who mentioned that while the proportion of men entering the nursing profession has been growing, it remains a female$P$ a g e | 42 dominated occupation.

The findings of the current study revealed that more than half of the study subjects were diploma nurses whom graduated from the secondary technical schools. In Egypt there are three types of nurses: college graduates, technical institute graduates and secondary technical schools, also known as diploma nurses. The first two types of nurses comprise four and two percent of the Egyptian nursing staff respectively, while diploma nurses make up the remaining $94 \%$. Recent reforms in the health sector eliminated the high school nursing by 2009 , allowing a gradual replacement of diploma nurses with baccalaureate graduates, thus bringing about a change in the already established role of college graduates as staff nurses having the leadership and prestigious positions in the hospital environment to assistant practical nurses who only obey the orders of the junior doctors and senior diploma nurses (Al Jarrah) ${ }^{(22) \text {. }}$

The results of the current study showed that the level of structural empowerment among studied nurses. Near to two third of studied nurses $(62.7 \%)$ have low structural empowerment level. While near to one third of them have moderate structural empowerment $(31.7 \%)$, and only $5.6 \%$ of them have high structural empowerment level. The study 
findings revealed that less than half of the staff nurses in the study sample had structural empowerment in their work environment.

This result was consistent with Hassona $^{(15)}$ who founded that more than half of the nursing staff (59\%) were not empowered at their work places and Rashed \& eldeen Fekry ${ }^{(23)}$ who indicated that nurses perceived work environment as it isn't allowed for complete manipulation of empowerment factors.

This result was inconsistent with the findings of Hassan (24) and El-Salam et al ${ }^{(25)}$ showed that, nurses had moderate access to empowerment factors in their work environment and with Comber\& Barribal ${ }^{(26)}$ who reported that nurses perceived themselves to be highly empowered. While, El Dahshan and Dorgham ${ }^{(27)}$,Fedai and Demir ${ }^{(28)}$, Bish, Kenny\&Nay (29); Lautizi (30) who founded that nurses experienced moderate level of structural empowerment. In addition, Mosela ${ }^{(31)}$ revealed that most of studied nurses at Benha University Hospital were moderately empowered.

This may be due to individuals receive lack recognition for their efforts, lack discretion in how they do their jobs and do not have access to support ,resources and information required to perform their work effectively .In addition ,they do not have opportunities to advance within the organization or to learn and grow through challenging work experiences or learning opportunities.

In the same line, Rashed \& Eldeen Fekry ${ }^{(23)}$ reported that the majority of staff nurses can deal with challenging work; as new technologies, advance treatment, modern supplies but they haven't chance to gain new skills and knowledge. Continuous education and development of staff nurses was very poor in hospitals. No chances to advance to better job. Generally in Egypt, the advancement to better job and the career ladder of nurses is not well established.

The result show that the level of psychological empowerment among studied nurses. Near to half of studied nurses $(49.7 \%)$ had low psychological empowerment level. While more than two third of them have moderate psychological empowerment (36.7\%), and only $13.6 \%$ of them had high psychological empowerment level.

In the same line with Ibrahim, Abo El-Magd \& Sayed (32) indicated that the majority of nurses university and teaching hospitals at Menofia Governorate/Egypt were perceived psychological empowerment as moderate level. Also, this result consistent with Nasiripour and Siadati ${ }^{(33)}$ who founded that nurses in Iran social security organization hospitals considered their empowerment status at moderate level. Corbally ${ }^{(34)}$ proved that the psychological empowerment has been viewed as having potential to play a key role in the professional development, increasing nurses' job satisfaction, giving a better quality for patients and included sense of meaning, self-determination, competence and impact.

This might be related to staff nurses at the bottom of the organizational hierarchy, have less experience, and knowledge making their effect in their workplace is weak, as related to staff nurses experienced low structural empowerment, where structural empowerment had a direct effect on psychological empowerment, when staff nurses become psychologically empowered; they can be adapting, able to cope with stressors, and more satisfied with the work. Their intent to stay in the organization increased and they become more loyal, more productive, and have the power to work in the organization.

The results illustrated that the level of job satisfaction among studied nurses. It noticed that more than two third of staff nurses have low job satisfaction $(68.3 \%)$. While, more than one quarter $(29.7 \%)$ have moderate job satisfaction and only $2 \%$ have high job satisfaction. The study findings revealed that less than half of the staff nurses in the study sample were satisfied with their job.

This result was in congruence with the foregoing results, (Hassona) ${ }^{(15)}$ showed that nearly half of the staff nurses were not satisfied with their job. The findings are also in agreement with Helal ${ }^{(35)}$ reported that about three quarters of nurses working at Zagazig university hospitals in Egypt was dissatisfied with all items of satisfaction in their study. On the other hand Morsy\& Sabra ${ }^{(36)}$ reported that more than two third of staff nurses $(68.9 \%)$ At Assuit university hospitals were satisfied with their work. Also, Salem, Baddar\& Mugatti (37) revealed the majority of nurses at Jeddah have fair satisfaction to their job.

This result was accorded with Hassan ${ }^{(24)}$ reported that most of the study subjects were dissatisfied with total job satisfaction. The findings also in agreement .In the opposed side, Ahmed, EL Molla \&Abed ${ }^{(38)}$ reported that $55 \%$ of the studied sample (clinical instructors at faculty of nursing, Cairo University) has moderate level of job satisfaction .also; there are highly positive correlation between overall job satisfactions. In the same line, Mohamed ${ }^{(39)}$ reported that $88.1 \%$ of the head nurses were satisfied compared to $75.2 \%$ of the staff nurses with a statistically significant difference $(p=0.03)$.

This result was accorded with Edoho, Bamidele\&Ojong Idang Neji ${ }^{(40)}$ founded that the majority of the nurses in public hospitals in calabar, cross river state Nigeria $265(82.4 \%)$ were moderately satisfied with their work. The findings also in agreement with A study was done by Laschinger et al (4) in Ontario, Canada among newly graduated nurses regarding job and career satisfaction and turnover intentions, suggested that lower the career satisfaction higher the intention to leave the profession.

This result was inconsistent with Damayanthi, Wichaikhum \& Chontawan ${ }^{(41)}$ who do a study bout "Predicting Factors of Job Satisfaction among Nurses in Sri Lanka" showed that the mean score of job satisfaction among nurses was 3.23 suggesting a moderate level of satisfaction. In line with findings Manju (42) reported in the study done in Coimbatore 2012 among 581 nurses that majority of the nurses were satisfied with the career.

Job satisfaction was low among staff nurses at Minia university hospital may be due to low benefits and incentives ,unclear salary items, decrease chances for continuous education, decrease chances for development, lack of support from supervisor and nurse manager, unpredictable monthly work schedule ,lack of clarity of organization policy ,continuous and fast changing of infection control instructions ,increase quantity of paper work, delaying doctors when needed, increasing work load, for old age increase in health problems, increase homework and responsibilities.

In this study, the results showed that the majority of studied group have low empowerment have low job satisfaction, more than two third of sample have moderate empowerment have moderate job satisfaction whereas the minority have high empowerment have high job satisfaction with a statistical significance difference,this in line with Rana $\&$ Singh ${ }^{(43)}$ done study in India to determine the relationship between employee empowerment and job satisfaction in IT industry, found that there is a significance relation between 
empowerment and job satisfaction and Saleh \& Saif (44) reported empowerment had a significant effect on overall employee job satisfaction.

Also, Baker ${ }^{(45)}$ found that the nurses are satisfied with their job feel empowered in their work place. This can be due to the empowerment play as a basic stone of satisfaction so, when level of empowerment low followed by low in job satisfaction. On the same hand Manojlovich, \& Laschinger, ${ }^{(46)}$ mentioned that the combination of structural and psychological empowerment was strong predictor of positive organizational outcomes especially job satisfaction.

\section{Conclusion}

The findings of this study provide evidence of the importance of workplace empowerment to achieve positive organizational outcomes in nursing. Exploring the impact of empowerment on nurses' work environments and understanding the relation between empowerment and job satisfaction might be useful for creating a supportive and satisfying work environment for nurses, which in turn could promote the intention to stay.

\section{Recommendations}

Nurse Mangers should assess the structures in their organizations to identify barriers of staff nurses to feel job security, ensure empowering factors at work, providing access to organizational empowering structures in order to make their employees have a greater sense of autonomy and impact at the workplaces

- Conduct periodic meeting and discussion between managers and staff nurses.

- Staff nurses should participate in developing organization's mission, philosophy, policies, vision, goals, including personal goals.

Further researches are recommended as:

- The relationship between empowerment and organizational climate

- The influence of empowerment on staff nurses performance

- Assessing factors influencing job satisfaction.

\section{References}

1) Cummings GG, MacGregor $T$, Davey $M$, Lee $H$, Wong CA, Lo E, et al. Leadership styles and outcome patterns for the nursing workforce and work environment: a systematic review. International journal of nursing studies. 2010;47(3):363-85.

2) Wagner, J. I., Cummings, G., Smith, D. L., Olson, J., Anderson, L., \& Warren, S. The relationship between structural empowerment and psychological empowerment for nurses: A systematic review.Journal of Nursing Management.2010; 18 (4), 448-62.

3) Hayes B, Bonner A, Pryor J. Factors contributing to nurse job satisfaction in the acute hospital setting: a review of recent literature. Journal of Nursing Management. 2010;18(7):804-14.

4) Laschinger HKS, Finegan J, Wilk P. Context matters: The impact of unit leadership and empowerment on nurses' organizational commitment. Journal of Nursing Administration. 2009;39(5):228-35.

5) Sellgren SF, Ekvall G, Tomson G. Leadership behaviour of nurse managers in relation to job satisfaction and work climate. Journal of nursing management. 2008;16(5):578-87.

6) Bateman TS, Snell AS. Management: Leading and collaborating in a competitive world. 11 ed. New York: McGraw -Hill Education 2015: 456.

7) Finkelman A \& Kenner C. Professional nursing concepts: competencies for quality leadership. Jones and Bartlett Publisher, Boston co., 2010: 108.

8) Spreitzer GM. Taking stock: A review of more than twenty years of research on empowerment at work. Handbook of organizational behavior. 2008:54-72.

9) Abadi MVNA, Chegini MG. Process of employee empowerment (concepts and dimensions). Kuwait Chapter of the Arabian Journal of Business and Management Review. 2013;2(11):76.

10) Jin-Liang $W$, Hai-Zhen $W$. The influences of psychological empowerment on work attitude and behavior in Chinese organizations. African Journal of Business Management. 2012;6(30):8938.

11) Ghale Hasan FH. Evaluation of Empowerment of Human Resources and Effectiveness, Journal of Basic and Applied Scientific Research.2012; 2(10):9998-10006

12) Burtson PL, Stichler JF. Nursing work environment and nurse caring: relationship among motivational factors. Journal of advanced nursing. 2010;66(8):1819-31.

13) Guerrettaz TA. Workplace empowerment, incivility and burnout: impact on staff nurse recruitment and retention outcomes. 2012.

14) (Manojlovich M. Power and Empowerment in Nursing: Looking Backward to Inform the Future. OJIN: The Online Journal of Issues in Nursing, 2007; 12 (1):1-15.

15) Hassona FMH. Relationship between Structural Empowerment, Work Engagement, and Job Satisfaction among Nursing Staff at Zagazig University Hospitals.2013;9(1):16-7.

16) Laschinger, H. K. S., Finegan, J., \&Shamian, J. The impact of workplace empowerment, organizational trust on staff nurses' work satisfaction and organizational commitment.Health Care Management Review.2001; 26(3): 7-23.

17) Kanter RM. Men and Women of the Corporation. 2nd ed: Basic books; 1993.

18) Spreitzer GM. Psychological empowerment in the workplace: Dimensions, measurement, and validation. Academy of management Journal. 1995;38(5):1442-65.

19) Mueller CW, McCloskey JC. Nurses' job satisfaction: a proposed measure. Nursing research. 1990;39(2):113-6.

20) McNutt J, Menon G. The rise of cyberactivism: Implications for the future of advocacy in the human services. Families in Society: The Journal of Contemporary Social Services. 2008; 89(1):33-8.

21) Yousef HR, El-Maged NSA, El-Houfey AA. Organizational Climate Correlates Nurses' Intention to Leave Work. Public Policy and Administration Research. 2014;4(4):14-21.

22) Al Jarrah IAT. Associate Nursing Students 'perceptions Toward Nursing Profession In Jordan. European Scientific Journal, ESJ. 2013;9(6).

23) Rashed NM, Eldeen Fekry NE. Workplace Empowerment as Perceived by Staff Nurses in Acute 
Health Care Hospitals. Journal of Biology, Agriculture and Healthcare .2015;5(12):91.

24) Hassan SH. Work empowerment versus job satisfaction among nurses at Mansoura university hospital :Master's Thesis .Faculty OF Nursing,Ain Shams University,cairo,Egypt;2007:80-90.

25) El-Salam G A, Ibrahim M M, Mohsen M M. \& Hassanein S E. Relationship Between Organizational Climate and Empowerment of nurses in Menoufiya hospitals, Egypt. Eastern Mediterranean Health Journal, 2008; 14 (5), 1173-83.

26) Comber B, Barriball KL. Impact of job satisfaction components on intent to leave and turnover for hospital-based nurses: a review of the research literature. International journal of nursing studies. 2007;44(2):297-314.

27) El Dahshan MEA, Dorgham LS. The Effect of Structural and Psychological Empowerment on Occupational Burnout in Staff Nurses Working in Shebin El-Kom Hospitals, Menoufiya Governernate, Egypt. Life Science Journal. 2013;10(1):3451-3.

28) Fedai,M.,\&Demir,Y. The impacts of Structral and Pychological Empowermrnt on Burnout :Canadian Social Science .2010;6(4):63-72.

29) Bish M, Kenny A, Nay R. A scoping review identifying contemporary issues in rural nursing leadership. Journal of Nursing Scholarship. 2012;44(4):411-7.

30) Lautizi M, Laschinger HK, Ravazzolo S. Workplace empowerment, job satisfaction and job stress among Italian mental health nurses: an exploratory study. Journal of nursing management. 2009;17(4):446-52.

31) Mosela,H.A. motivating work function and empowerment among staff nurses at Benha University Hospital :Master's thesis .Faculty of Nursing, Benha university ;2012: 12-42.

32) Ibrahim MM, El-Magd MHA, Sayed HY. Nurse's psychological empowerment and perceived autonomy in university and teaching hospitals at Menofia Governorate/Egypt. Journal of Nursing Education and Practice. 2014;4(9):59.

33) Nasiripour A. \& Siadati S. A Propose Model for Nurses Empowerment through Characteristics of Workplace and Management Strategies; A Study in Iranian Hospitals, Australian Journal of Basic and Applied Sciences. 2011; 5(6): 906-11

34) Corbally M.A., ScottP.A., MatthewsA., GabhannL.M. \& MurphyC. Irish Nurses' and
Midwives' Understanding and Experiences of Empowerment. Journal of Nursing Management. 2007; 15: 169-79. PMid:17352700

35) Helal W E H. Leadership styles of the head nurses and its relationship to their staff nurses' job satisfaction and motivation. Master Thesis. Faculty of Nursing, Zagazig University, Egypt, 2008.

36) Morsy \& Sabra. Relationship between quality of work life and nurses job satisfaction at assuit university hospitals.2015;13(1):167-9.

37) Salem OA, Baddar F, AL-Mugatti HM. Relationship between Nurses Job Satisfaction and Organizational Commitment. Journal of Nursing and Health Science.2016;5(1):54.

38) Ahmed S. A., El Molla M. \& Abed F. Effect of Organizational Climate on Job Satisfaction of Clinical Instructors at the Faculty of Nursing, Cairo Univeristy, medical journal of cairo university .2014; 82(2): 17-21.

39) Mohamed FR. Nurses 'satisfaction With Work Environment At Assuit University Hospital. AAMJ. 2010;8(2):73-5.

40) Edoho S, Bamidele E, Neji OI, Frank AE. Job Satisfaction among Nurses in Public Hospitals in Calabar, Cross River State Nigeria. American Journal of Nursing Science. 2015;4(4):231-7.

41) Damayanthi H, Wichaikhum O, Chontawan R. Predicting factors of job satisfaction among nurses in Sri Lanka. International Journal of Pharmacy \& BioSciences. 2014;1(1):5.

42) Manju, R.Work life Balance \& Career Satisfaction of Critical Care Nurses in Private Hospitals at Coimbatore: Indian Journal of Applied Research. November;2012 2(2):113-44.

43) Rana A., Singh V. Employee Empowerment And Job Satisfaction: An Empirical Study Of Manufacturing Sector.2016;21(10):23-9.

44) Saleh A., Saif N. Psychological empowerment and job satisfaction in Jordanian hospitals. International Journal of Humanities and Social Science. 2013;3(16):250-7.

45) Baker SL, Fitzpatrick JJ, Griffin MQ. Empowerment and job satisfaction in associate degree nurse educators. Nursing Education Perspectives. 2011;32(4):234-9.

46) Manojlovich $M$, Laschinger $H$. The nursing worklife model: extending and refining a new theory. Journal of Nursing Management. 2007;15(3):256-63. 